\title{
Assessment of Inorganic Contaminants in Golden Mussel (Limnoperna fortunei) in Southern Brazil
}

\author{
Éderson R. Pereira, ${ }^{a}$ Bruno M. Soares, ${ }^{a}$ João P. Vieira, ${ }^{b}$ Ana C. G. Mai, ${ }^{b}$ \\ Rochele S. Picoloto, ${ }^{c}$ Edson I. Muller, ${ }^{c}$ Erico M. M. Flores ${ }^{c}$ and Fábio A. Duarte ${ }^{*, a}$ \\ ${ }^{a}$ Escola de Química e Alimentos and ${ }^{b}$ Instituto de Oceanografia, \\ Universidade Federal do Rio Grande, 96203-900 Rio Grande-RS, Brazil \\ 'Departamento de Química, Universidade Federal de Santa Maria, \\ 97105-900 Santa Maria-RS, Brazil
}

\begin{abstract}
Elementos traço e majoritários foram determinados em mexilhão dourado (Limnoperna fortunei) coletados no canal São Gonçalo (Rio Grande-RS, Brasil). Digestão assistida por microondas em sistema fechado foi utilizada para decomposição das amostras com subsequente determinação elementar por técnicas espectrométricas. Os resultados mostraram que o tecido de mexilhão contém Ag, Al, As, B, Ba, Ca, Cd, Co, Cr, Cu, Fe, Hg, Li, Mg, Mn, Mo, P, Pb, S, Sn, Sr, Ti, V e Zn, enquanto que na casca foram encontrados os mesmo elementos, exceto $\mathrm{Ag}$ e $\mathrm{Hg}$, evidenciando seu potencial como biomarcador. Neste sentido, estes resultados podem ser utilizados para estabelecer um panorama inicial e contribuir para futuros estudos relacionados a contaminantes inorgânicos na área estudada.
\end{abstract}

Major and trace element content was determined in golden mussel (Limnoperna fortunei) collected in the São Gonçalo Channel (Rio Grande City, Brazil). A microwave-assisted digestion procedure in closed vessels was applied to mussel decomposition and subsequent determination of elements by spectrometric techniques. Results showed that the mussel tissue contains Ag, Al, As, B, Ba, Ca, Cd, Co, Cr, Cu, Fe, Hg, Li, Mg, Mn, Mo, P, Pb, S, Sn, Sr, Ti, V and Zn, while the same elements (except $\mathrm{Ag}$ and $\mathrm{Hg}$ ) were quantified in its shell, demonstrating its potential as a biomarker. In this sense, these results can be used to establish an initial view and to contribute to further studies related to element contamination in the area under study.

Keywords: inorganic contaminants, microwave-assisted digestion, Limnoperna fortunei, spectrometric techniques

\section{Introduction}

Bivalves have been widely used as sentinel organisms for environmental change monitoring that is related to trace element levels in aquatic ecosystems. ${ }^{1,2}$ Bivalve are chosen for this purpose due to their wide distribution, extensive populations, sedentary and filter-feeding habits, besides their bioaccumulation capacity. ${ }^{3}$

The golden mussel Limnoperna fortunei (Bivalvia: Mytilidae) (Dunker, 1857) is an Asian freshwater mussel that was first found (in South America, 1991) ${ }^{4}$ in colonies practically all along the La Plata River in Argentina, ${ }^{4-6}$ and in parts of Bolivia, Paraguay, ${ }^{7}$ Uruguay $^{8}$ and Brazil, at densities reaching over 200000 individuals per $\mathrm{m}^{2} .{ }^{9}$ Since

*e-mail: fabioand@gmail.com then, Limnoperna fortunei has already colonized the entire Paraguay River (an extension of $1718 \mathrm{~km}$ ) and spread to Brazilian states, such as Mato Grosso do Sul, São Paulo $^{10,11}$ and Paraná. ${ }^{12}$

In Rio Grande do Sul State (Brazil), the golden mussel has been detected since $1998 .^{9}$ This species has already colonized the Guaíba Lake, ${ }^{9,13}$ causing serious incrustations in water supply facilities. ${ }^{14}$ The first record of Limnoperna fortunei above the water gate of the São Gonçalo Channel and the Mirim Lagoon was made in 2005, and the dispersion may have happened via São Gonçalo Channel that connects both Patos and Mirim Lagoons. ${ }^{15}$

The combination of early sexual maturity, high fecundity index and wide environmental tolerance enables Limnoperna fortunei to be a successful invader of new environments. ${ }^{13}$ With these characteristics added to their 
high filtration power (133 to $350 \mathrm{~mL} \mathrm{~h}^{-1}$ per individual), ${ }^{16}$ these mussels can be used as sentinels ${ }^{17}$ of chemical distribution and levels of elements in aquatic ecosystems. ${ }^{5}$

The characterization of this biomarker in different locations can simultaneously provide information on the pollution status of the region and better comprehension of response mechanisms that these organisms use against the pollutants. ${ }^{18,19}$ In a recent study, ${ }^{20}$ a screening survey of trace element contamination in Meretrix spp. (Mollusca: Bivalvia: Veneridae) collected in three regions in Vietnam was carried out. Likewise, Mytilus galloprovincialis has been used in the Eastern part of the Black Sea (Turkey) to monitor the effect of mine pollution by element determination in the tissue and shell of these mussels. ${ }^{2}$ In Flanders (Belgium), zebra mussels (Dreissena polymorpha) were evaluated as indicators of micro-pollution in freshwater environment. ${ }^{21}$

Trace element determination has always been an analytical problem, especially at the relatively low natural concentration in aquatic organisms. Generally, a wide range of elements in concentration levels from $\mathrm{ng} \mathrm{g}^{-1}$ to $\mu \mathrm{g} \mathrm{g}^{-1}$ can be measured in a single analysis. ${ }^{2}$ Analytical techniques, such as flame atomic absorption spectrometry (FAAS) and electrothermal atomic absorption spectrometry (ETAAS), have been used for trace element determination. However, the limits of detection (especially for FAAS) may not be sufficient for several elements found in a sample solution. ${ }^{22-24}$ In addition, the ETAAS technique is not so versatile as plasma-based techniques. Other techniques have been used for elemental determination, such as inductively coupled plasma mass spectrometry (ICP-MS) and inductively coupled plasma optical emission spectrometry (ICP-OES) in different matrices. ${ }^{25-27}$ These techniques have been successfully applied to trace element determination in mussel samples. ${ }^{20,21}$ Inductively coupled plasma optical emission spectrometry is attractive due to its multielemental capability. However, the limits of detection (LOD) for some elements are not sufficiently low yet. ${ }^{26} \mathrm{On}$ the other hand, since ICP-MS is one of the most sensitive analytical techniques, it is suitable for multielemental determination at trace and ultra-trace levels in different sample matrices. ${ }^{25,27}$ However, matrix effects can increase LOD and cause interferences. ${ }^{26}$ Therefore, the sample preparation step is an important parameter to obtain suitable results when using plasma-based techniques. Usually, many procedures for biological matrix pretreatments, ${ }^{28}$ such as microwave-assisted digestion (MAD) ${ }^{29}$ ultrasound-assisted extraction (UAE) ${ }^{28}$ and combustion techniques, ${ }^{30,31}$ have been used. Microwave-assisted wet digestion in closed vessels, in view of its high digestion efficiency, relatively low reagent consumption and reduced risks of losses and contamination, by comparison with conventional digestion procedures, has been widely employed as a sample preparation method for different matrices. ${ }^{26,32}$

The purpose of this study was to investigate the element concentration in Limnoperna fortunei collected in the São Gonçalo Channel. This mussel can be used as a biomarker of aquatic pollution in the channel. Twenty four elements (Ag, $\mathrm{Al}, \mathrm{As}, \mathrm{B}, \mathrm{Ba}, \mathrm{Ca}, \mathrm{Cd}, \mathrm{Co}, \mathrm{Cr}, \mathrm{Cu}, \mathrm{Fe}$, $\mathrm{Hg}, \mathrm{Li}, \mathrm{Mg}, \mathrm{Mn}, \mathrm{Mo}, \mathrm{P}, \mathrm{Pb}, \mathrm{S}, \mathrm{Sn}, \mathrm{Sr}, \mathrm{Ti}, \mathrm{V}$ and $\mathrm{Zn}$ ) were determined in the tissue, shell and whole golden mussel by ICP-MS and ICP OES. Accuracy was evaluated by using certified reference materials (CRMs). Samples were digested by using microwave radiation in high-pressure closed vessels.

\section{Experimental}

\section{Sampling and sample procedure}

The field sampling procedure took place at daytime on November $21^{\text {st }}, 2010$, in the limnic portion of the São Gonçalo Channel, in waters 3 to $6 \mathrm{~m}$ deep (see Supplementary Information section), specifically in a place named "Sangradouro" (lat.: 32॰10’01" S; long.: 52॰39’02” W), where the São Gonçalo Channel flows into the Mirim Lagoon. Two distinct sampling devices were used: 15 sampling processes were performed with a Picard dredge $(10 \times 40 \mathrm{~cm})$ and 12 sampling processes were performed with a bottom trawl net $(10.5 \mathrm{~m}$ head rope, $1.3 \mathrm{~cm}$ bar mesh wings and body with a $0.5 \mathrm{~cm}$ bar mesh cod end liner). A pair of weighted outer doors (15 kg each) was dragged for $400 \mathrm{~m}$ by a wooden boat (12 m long) equipped with 60 HP engines.

A total of 133077 Limnoperna fortunei was collected and stored in plastic bags and polypropylene vessels. The majority of the individuals was collected by using a bottom trawl $(\mathrm{n}=111739,84 \%)$ and the remaining individuals $(n=21338,16 \%)$ were collected by using a Picard dredge. Samples were preserved in ice and taken to the laboratory. All samples were maintained frozen $\left(-20^{\circ} \mathrm{C}\right)$ before the analyses.

The size ranges of the golden mussels, by comparison with those reported in the literature ${ }^{33,34}$ suggest that the majority of the golden mussel individuals (133077) can be considered adults above 2 years old ( $>17 \mathrm{~mm}$ total length). It means that the colonization had started long before the sampling date.

A representative portion (1\%) was separated from the total number (133077) into three subsamples [shell, tissue and whole (shell + tissue) mussel] for the subsequent digestion procedure. Shell samples were oven dried at $50{ }^{\circ} \mathrm{C}$ for $5 \mathrm{~h}$ and, afterwards, transferred to a mortar and gently blended to obtain homogeneity and particle size 
smaller than $120 \mu \mathrm{m}$. Tissue and whole samples were oven dried at $50{ }^{\circ} \mathrm{C}$ for $24 \mathrm{~h}$ and then transferred separately to a mortar and gently blended to obtain homogeneity and particle size smaller than $180 \mu \mathrm{m}$.

\section{Reagents}

All reagents used in this study were of analytical grade. Distilled and deionized water used to prepare all reagents and reference solutions was purified by using a Milli-Q system (Millipore Corp., Bedford, USA). Concentrated $\mathrm{HNO}_{3}$ and $\mathrm{HCl}$ (Merck, Darmstadt, Germany) were purified by using a sub-boiling system (Milestone, Model Duopur, Bergamo, Italy). Hydrogen peroxide $30 \%(\mathrm{~m} / \mathrm{v})$ was purchased from Synth (Diadema, Brazil). Sodium tetrahydroborate (Vetec, Duque de Caxias, Brazil) solution $(0.1 \%, \mathrm{~m} / \mathrm{v})$ was daily prepared by dissolving the solid reagent in $0.01 \%(\mathrm{~m} / \mathrm{v})$ $\mathrm{NaOH}$ solution (Merck). A multielemental reference stock solution (SCP33MS, SCP Science, Quebec, Canada) containing $10 \mathrm{mg} \mathrm{L}^{-1} \mathrm{Ag}, \mathrm{Al}, \mathrm{As}, \mathrm{B}, \mathrm{Ba}, \mathrm{Ca}, \mathrm{Cd}, \mathrm{Co}, \mathrm{Cr}, \mathrm{Cu}$, $\mathrm{Fe}, \mathrm{Li}, \mathrm{Mg}, \mathrm{Mn}, \mathrm{Mo}, \mathrm{Pb}, \mathrm{Sn}, \mathrm{Sr}, \mathrm{Ti}, \mathrm{V}$ and $\mathrm{Zn}$ was used to prepare reference solutions in $5 \%(\mathrm{~m} / \mathrm{v}) \mathrm{HNO}_{3}$ in the range from 5 to $100 \mu \mathrm{g} \mathrm{L}-1$ for ICP OES and from 0.025 to $10 \mu \mathrm{g} \mathrm{L}^{-1}$ for ICP-MS. Mercury standard solutions in the range from 0.025 to $1 \mu \mathrm{g} \mathrm{L} \mathrm{L}^{-1}$ for CV-ICP-MS were prepared by serial dilution of a $1000 \mathrm{mg} \mathrm{L}^{-1}$ stock standard solution (Merck) in $5 \%(\mathrm{~m} / \mathrm{v}) \mathrm{HNO}_{3}$. For sulfur determination, reference solutions (in the range from 0.1 to $10 \mathrm{mg} \mathrm{L}^{-1}$ ) were prepared with the serial dilution of a stock solution (1000 $\left.\mathrm{mg} \mathrm{L}^{-1}\right)$ (Spex CertiPrep, Metuchen, USA) in ultra-pure water. For phosphorus determination, reference solutions (in the range from 0.1 to $10 \mathrm{mg} \mathrm{L}^{-1} \mathrm{P}$ ) were prepared with the serial dilution of a stock solution (1000 $\mathrm{mg} \mathrm{L}^{-1} \mathrm{PO}_{4}^{3-}$ ) (Merck) in ultra-pure water.

\section{Instrumentation}

A microwave sample preparation system (Multiwave 3000, Anton Paar, Graz, Austria) equipped with eight high-pressure quartz vessels $(80 \mathrm{~mL})$ was used for sample digestion. Temperature and pressure were controlled during the heating program (maximum pressure and temperature were $80 \mathrm{bar}$ and $280^{\circ} \mathrm{C}$, respectively).

Element determination in mussel (shell, tissue and whole mussel) was performed by using an inductively coupled plasma optical emission spectrometer with axial view configuration (Model Spectro Ciros CCD, Spectro Analytical Instruments, Kleve, Germany) equipped with a cross flow nebulizer coupled to a double pass-Scott type spray chamber. An inductively coupled plasma mass spectrometer (PerkinElmer Sciex, Model Elan DRC II,
Thornhill, Canada), equipped with a concentric nebulizer (Meinhard Associates, Golden, USA), a cyclonic spray chamber (Glass Expansion, Inc., West Melbourne, Australia) and a quartz torch with a quartz injector tube ( $2 \mathrm{~mm}$ i.d.), was also used for the element determination. Mercury was determined by using a cold vapor (CV) system coupled to ICP-MS by a continuous flow (CF) system. This system was built according to a previous study: ${ }^{26}$ it uses CF instead of flow injection. Briefly, it consists of a CV system, composed by a peristaltic pump (Gilson, Miniplus, France), a manual injector and a U-type gasliquid separator. Tygon ${ }^{\circledR}$ tubes with internal diameter of $1.14 \mathrm{~mm}$ were used to carry both $0.1 \%(\mathrm{~m} / \mathrm{v}) \mathrm{NaBH}_{4}$ and $1.0 \mathrm{~mol} \mathrm{~L}^{-1} \mathrm{HCl}$ solutions, whereas a tube with internal diameter of $1.69 \mathrm{~mm}$ was used to carry water (which was the sample carrier). The sample was mixed with $1.0 \mathrm{~mol} \mathrm{~L}^{-1}$ $\mathrm{HCl}$ by using a T-type connector $(0.8 \mathrm{~mm}$ i.d.) and carried to another T-type connector ( $0.8 \mathrm{~mm}$ i.d.), where a $\mathrm{NaBH}_{4}$ solution was also on-line mixed. The mixture was pumped to the gas-liquid separator and $\mathrm{Hg}$ was measured by ICP-MS. For spectrometer optimization, the radiofrequency (RF) power and the argon flow rate were optimized. RF power was evaluated from 1000 to $1500 \mathrm{~W}$ with increases of $100 \mathrm{~W}$. Plasma, auxiliary and nebulizer gas flow rates were evaluated, ranging from 12 to $15,0.8$ to 1.5 and 0.6 to $1.2 \mathrm{~L} \mathrm{~min}^{-1}$, respectively. For ICP-MS and ICP OES, the wavelengths and the isotopes were selected as the most sensitive and interference-free ones. The operating conditions for element determination by ICP-MS and ICP OES are described in Table 1.

Argon 99.996\% (White Martins - Praxair, São Paulo, Brazil) was used for plasma generation, nebulization and auxiliary gas.

\section{Microwave-assisted digestion}

Dried and ground samples of golden mussel $(0.250 \mathrm{~g}$ tissue, shell or whole mussel) were transferred to quartz tubes and $5 \mathrm{~mL}$ concentrated $\mathrm{HNO}_{3}$ and $1 \mathrm{~mL} 30 \% \mathrm{H}_{2} \mathrm{O}_{2}$ were added. The heating program was carried out according to the manufacturer recommendations, ${ }^{35}$ as follows: (i) $600 \mathrm{~W}$ for $5 \mathrm{~min}$ ( $5 \mathrm{~min}$ of ramp), (ii) $1400 \mathrm{~W}$ for $5 \mathrm{~min}$ ( $5 \mathrm{~min}$ of ramp) and (iii) $0 \mathrm{~W}$ for $20 \mathrm{~min}$. After cooling, digests were diluted with water to $30 \mathrm{~mL}$ in polypropylene vessels for further analysis. It is important to point out that the irradiation program was run $2 \mathrm{~h}$ after the reagents were added to the samples. This procedure was necessary due to the high carbonate concentration found in the shells. Otherwise, the pressure inside the vessels would increase quickly.

Accuracy was evaluated by using CRMs of oyster tissue (SRM 1566b) and natural water (SRM 1640), both 
Table 1. Operational parameters for element determination by ICP-MS and ICP OES

\begin{tabular}{|c|c|c|}
\hline Parameter & ICP-MS & ICP OES \\
\hline RF power / W & 1300 & 1500 \\
\hline $\begin{array}{l}\text { Plasma gas flow } \\
\text { rate / }\left(\mathrm{L} \mathrm{min}^{-1}\right)\end{array}$ & 15.0 & 14.0 \\
\hline $\begin{array}{l}\text { Auxiliary gas flow } \\
\text { rate / }\left(\mathrm{L} \mathrm{min}^{-1}\right)\end{array}$ & 1.2 & 1.0 \\
\hline $\begin{array}{l}\text { Nebulizer gas flow } \\
\text { rate / }\left(\mathrm{L} \mathrm{min}^{-1}\right)\end{array}$ & 1.13 & 0.90 \\
\hline Spray chamber & cyclonic & double pass \\
\hline Nebulizer & concentric & cross flow \\
\hline $\begin{array}{l}\text { Sampler and } \\
\text { skimmer cones }\end{array}$ & $\mathrm{Pt}$ & - \\
\hline Isotopes $(\mathrm{m} / \mathrm{z})$ & $\begin{array}{l}{ }^{107} \mathrm{Ag},{ }^{75} \mathrm{As},{ }^{111} \mathrm{Cd}, \\
{ }^{9} \mathrm{Co},{ }^{53} \mathrm{Cr},{ }^{63} \mathrm{Cu}, \\
{ }^{202} \mathrm{Hg},{ }^{7} \mathrm{Li},{ }^{55} \mathrm{Mn}, \\
{ }^{97} \mathrm{Mo},{ }^{208} \mathrm{~Pb},{ }^{18} \mathrm{Sn}, \\
{ }^{86} \mathrm{Sr},{ }^{47} \mathrm{Ti},{ }^{51} \mathrm{~V},{ }^{66} \mathrm{Zn}\end{array}$ & \\
\hline Wavelength / nm & & $\begin{array}{c}\mathrm{Ag}(338.289), \mathrm{Al}(167.078), \\
\mathrm{As}(189.042), \mathrm{B}(249.773), \\
\mathrm{Ba}(455.404), \mathrm{Ca}(317.933), \\
\mathrm{Cd}(214.438), \mathrm{Co}(228.616), \\
\mathrm{Cr}(267.716), \mathrm{Cu}(324.754), \\
\mathrm{Fe}(238.204), \mathrm{Li}(460.289), \\
\mathrm{Mg}(279.553), \mathrm{Mn}(257.611), \\
\mathrm{Mo}(202.030), \mathrm{P}(177.495), \\
\mathrm{Pb}(220.353), \mathrm{S}(182.034), \\
\mathrm{Sn}(189.991), \mathrm{Sr}(421.552), \\
\mathrm{Ti}(336.121), \mathrm{V}(292.464), \\
\mathrm{Zn}(206.191)\end{array}$ \\
\hline
\end{tabular}

were obtained at the National Institute of Standards and Technology (NIST, Gaithersburg, USA).

All statistical calculations were performed by using the GraphPad InStat (GraphPad InStat Software Inc, version 3.00, 1997) software. A 95\% significance level was adopted for all comparisons.

\section{Results and Discussion}

The concentration of some elements in mussels (e.g. Limnoperna fortunei) can provide data about potential pollutants in the aquatic environment. In this sense, the element concentration in tissue and shell should necessarily be known. ${ }^{2}$ The total element concentration in golden mussel samples (tissue, shell and whole) are shown in Table 2. Results for all elements represent the average values and standard deviation for $n=3$.

Results show that tissue and shell of Limnoperna fortunei contain detectable concentrations of 24 elements determined by ICP-MS or ICP OES, except $\mathrm{Ag}$ and $\mathrm{Hg}$ concentrations in shell that were lower than 0.013 and $0.05 \mu \mathrm{g} \mathrm{g}^{-1}$, respectively (Table 2 ).
Among the elements under evaluation, the $\mathrm{Ca}$ concentration was the highest in tissue $\left(13.5 \pm 0.5 \mathrm{mg} \mathrm{g}^{-1}\right)$ and shell $\left(359 \pm 8 \mathrm{mg} \mathrm{g}^{-1}\right)$. Although $\mathrm{Ca}$ is reported for the first time for Limnoperna fortunei, its concentration is in agreement with previously reported values for other mussel species, it ranges from 7.0 to $20 \mathrm{mg} \mathrm{g}^{-1}$ and 490 to $647 \mathrm{mg} \mathrm{g}^{-1}$ for tissue and shell, respectively. ${ }^{2}$ For other major elements, such as $\mathrm{Al}, \mathrm{S}$ and $\mathrm{P}$, total concentration was $3092 \pm 62,6454 \pm 314$ and $9113 \pm 357 \mu \mathrm{g} \mathrm{g}^{-1}$ for tissue and $158 \pm 3,1031 \pm 88$ and $302 \pm 20 \mu \mathrm{g} \mathrm{g}^{-1}$ for shell, respectively. The $\mathrm{Al}$ concentration found in the whole mussel was $403 \pm 7 \mu \mathrm{g} \mathrm{g}^{-1}$, being higher than the one reported for the same species of mussel Limnoperna fortune that ranged from 5 to $25 \mu \mathrm{g} \mathrm{g}^{-1} .{ }^{36}$

For Fe, values were $1881 \pm 91 \mu \mathrm{g} \mathrm{g}^{-1}$ for tissue and $322 \pm 17 \mu \mathrm{g} \mathrm{g}^{-1}$ for shell. The iron concentration found in the whole mussel was $540 \pm 26 \mu \mathrm{g} \mathrm{g}^{-1}$, being much higher than the one reported for the same mussel (from 5 to $\left.25 \mu \mathrm{g} \mathrm{g}^{-1}\right)^{36}$ and higher than the one reported for the Mediterranean blue mussel tissue (Mytilus galloprovincialis). ${ }^{37}$ However, the values found in this study are in agreement with those reported in the literature for other mussel species that ranged from 1150 to $4030 \mu \mathrm{g} \mathrm{g}^{-1}$.

Values found for $\mathrm{B}, \mathrm{Mn}$ and $\mathrm{Mg}$ in tissue were $5.0 \pm 0.7$, $236 \pm 5$ and $651 \pm 51 \mu \mathrm{g} \mathrm{g}^{-1}$, respectively, while the concentrations of these elements in shell were $1.45 \pm 0.10$, $106 \pm 1$ and $140 \pm 5 \mu \mathrm{g} \mathrm{g}^{-1}$, respectively. The manganese concentration was higher than the one reported for other mussel species, from 8.1 to $59 \mu \mathrm{g} \mathrm{g}^{-1}$ for tissue ${ }^{2,20}$ and from 11 to $39 \mu \mathrm{g} \mathrm{g}^{-1}$ for shell. ${ }^{2}$ It is important to point out that manganese is an essential element which can be actively assimilated by plants and animals. ${ }^{38}$ For magnesium, the value found in the whole mussel was $206 \pm 4 \mu \mathrm{g} \mathrm{g}^{-1}$ that is in agreement with the one reported in the literature for the same species. ${ }^{36}$

The barium content in these samples was $143 \pm 2$ and $219 \pm 7 \mu \mathrm{g} \mathrm{g}^{-1}$ for tissue and shell, respectively. The concentration found in the tissue was higher than the one reported in the literature for other mussel species. ${ }^{20}$

In most studies related to trace element determination in mussel species, some elements such as $\mathrm{Cu}, \mathrm{Cd}$ and $\mathrm{Zn}$ receive special attention. In this study, the concentration of these elements was $10.0 \pm 1.1$ and $0.84 \pm 0.09,1.19 \pm 0.19$ and $0.026 \pm 0.006,80 \pm 4$ and $3.4 \pm 0.9 \mu \mathrm{g} \mathrm{g}^{-1}$ for tissue and shell, respectively. Element concentration in mussel tissue is comparable with the recently reported values for the same mussel, ${ }^{39}$ whose concentrations are in agreement with reported values (range from 8.7 to 14 and 0.7 to $2.1 \mu \mathrm{g} \mathrm{g}^{-1}$ for $\mathrm{Cu}$ and $\mathrm{Cd}$, respectively). However, the $\mathrm{Zn}$ concentration was higher than the one reported for the same kind of mussel (48 to $\left.72 \mu \mathrm{g} \mathrm{g}^{-1}\right) .{ }^{39}$ On the other hand, results found in this study 
Table 2. Results for element concentration (mean \pm standard deviation in $\mu \mathrm{g} \mathrm{g}^{-1}, n=3$ ) in Limnoperna fortunei (tissue, shell and whole) by MAD for sample digestion and determination by ICP OES and ICP-MS

\begin{tabular}{|c|c|c|c|c|c|c|}
\hline \multirow{2}{*}{ Element / $\left(\mu \mathrm{g} \mathrm{g}^{-1}\right)$} & \multicolumn{2}{|c|}{ Tissue } & \multicolumn{2}{|c|}{ Shell } & \multicolumn{2}{|c|}{ Whole } \\
\hline & ICP OES & ICP-MS & ICP OES & ICP-MS & ICP OES & ICP-MS \\
\hline$\overline{\mathrm{Ag}}$ & $<1.5$ & $0.140 \pm 0.018$ & $<0.91$ & $<0.013^{\mathrm{b}}$ & $<0.91$ & $<0.013^{b}$ \\
\hline $\mathrm{Al}$ & $3092 \pm 62$ & nd & $158 \pm 2$ & nd & $403 \pm 7$ & nd \\
\hline As & $<6.5^{\mathrm{b}}$ & $3.5 \pm 0.4$ & $<1.76^{\mathrm{b}}$ & $0.29 \pm 0.03$ & $<1.76^{\mathrm{b}}$ & $0.64 \pm 0.08$ \\
\hline $\mathrm{B}$ & $5.0 \pm 0.7$ & nd & $1.45 \pm 0.10$ & nd & $1.56 \pm 0.33$ & nd \\
\hline $\mathrm{Ba}$ & $143 \pm 2$ & nd & $219 \pm 7$ & nd & $228 \pm 4$ & nd \\
\hline $\mathrm{Ca}$ & $13512 \pm 549$ & nd & $358795 \pm 8172$ & nd & $328409 \pm 7629$ & nd \\
\hline $\mathrm{Cd}$ & $1.35 \pm 0.13$ & $1.19 \pm 0.19$ & $<0.141$ & $0.026 \pm 0.006$ & $0.20 \pm 0.03$ & $0.18 \pm 0.01$ \\
\hline Co & $1.73 \pm 0.15$ & $1.62 \pm 0.22$ & $<1.02^{\mathrm{b}}$ & $0.76 \pm 0.05$ & $0.50 \pm 0.07$ & $0.52 \pm 0.02$ \\
\hline $\mathrm{Cr}$ & $9.5 \pm 0.4$ & $9.7 \pm 1.0$ & $5.8 \pm 0.2$ & $5.2 \pm 0.6$ & $9.8 \pm 1.6$ & $10.0 \pm 1.1$ \\
\hline $\mathrm{Cu}$ & $10.5 \pm 0.3$ & $10.0 \pm 1.1$ & $<2.0^{\mathrm{b}}$ & $0.84 \pm 0.09$ & $<2.0^{\mathrm{b}}$ & $1.22 \pm 0.09$ \\
\hline $\mathrm{Fe}$ & $1881 \pm 91$ & nd & $322 \pm 17$ & nd & $540 \pm 26$ & nd \\
\hline $\mathrm{Hg}^{\text {a }}$ & nd & $0.070 \pm 0.005$ & $\mathrm{Nd}$ & $<0.05^{\mathrm{b}}$ & nd & $<0.05^{\mathrm{b}}$ \\
\hline $\mathrm{Li}$ & $<18.9^{\mathrm{b}}$ & $1.41 \pm 0.23$ & $<18.9^{\mathrm{b}}$ & $0.013 \pm 0.001$ & $<18.9^{\mathrm{b}}$ & $0.080 \pm 0.006$ \\
\hline $\mathrm{Mg}$ & $651 \pm 51$ & nd & $140 \pm 5$ & nd & $206 \pm 4$ & nd \\
\hline $\mathrm{Mn}$ & $236 \pm 5$ & $203 \pm 29$ & $106 \pm 1$ & $104 \pm 6$ & $132 \pm 3$ & $153 \pm 17$ \\
\hline Mo & $<1.28^{\mathrm{b}}$ & $1.02 \pm 0.18$ & $<1.28^{\mathrm{b}}$ & $0.21 \pm 0.01$ & $<1.28^{\mathrm{b}}$ & $0.13 \pm 0.02$ \\
\hline $\mathrm{P}$ & $9113 \pm 357$ & nd & $302 \pm 19$ & nd & $1899 \pm 60$ & nd \\
\hline $\mathrm{Pb}$ & $6.6 \pm 0.5$ & $7.2 \pm 1.1$ & $<2.7^{\mathrm{b}}$ & $0.20 \pm 0.03$ & $<2.7^{\mathrm{b}}$ & $0.39 \pm 0.06$ \\
\hline S & $6454 \pm 314$ & nd & $1031 \pm 88$ & nd & $1961 \pm 74$ & nd \\
\hline Sn & $<18.0^{\mathrm{b}}$ & $3.4 \pm 0.6$ & $<18.0^{\mathrm{b}}$ & $13.6 \pm 0.4$ & $<18.0^{\mathrm{b}}$ & $8.0 \pm 1.2$ \\
\hline $\mathrm{Sr}$ & $50 \pm 1$ & $49 \pm 3$ & $532 \pm 52$ & $574 \pm 21$ & $475 \pm 11$ & $488 \pm 64$ \\
\hline $\mathrm{Ti}$ & $73 \pm 4$ & $73 \pm 7$ & $<8.0^{\mathrm{b}}$ & $3.8 \pm 0.8$ & $20.0 \pm 0.2$ & $18.0 \pm 2.6$ \\
\hline $\mathrm{V}$ & $5.4 \pm 0.3$ & $5.8 \pm 0.9$ & $0.99 \pm 0.07$ & $0.96 \pm 0.07$ & $1.44 \pm 0.13$ & $1.03 \pm 0.09$ \\
\hline$\underline{\mathrm{Zn}}$ & $82 \pm 2$ & $80 \pm 4$ & $3.9 \pm 0.1$ & $3.4 \pm 0.9$ & $11.5 \pm 0.3$ & $11.2 \pm 0.4$ \\
\hline
\end{tabular}

${ }^{a}$ Determination by CV-ICP-MS; ${ }^{b}$ LOQ: limit of quantification $(10 \sigma, \sigma=$ standard deviation of ten measurements of blank solution), $n=10$; nd: not determined.

for shell were lower than values reported in the literature for other mussel species. ${ }^{2}$ They ranged from 110 to 180 and 1 to $2 \mu \mathrm{g} \mathrm{g}^{-1}$ for $\mathrm{Cu}$ and $\mathrm{Cd}$, respectively.

The concentration of $\mathrm{V}, \mathrm{Cr}$ and $\mathrm{Ti}$ was $5.8 \pm 0.9$, $9.7 \pm 1.0$ and $73 \pm 7 \mu \mathrm{g} \mathrm{g}{ }^{-1}$ in tissue and $0.96 \pm 0.07$, $5.2 \pm 0.6$ and $3.8 \pm 0.8 \mu \mathrm{g} \mathrm{g}^{-1}$ in shell. The titanium concentration found in the whole mussel was $18.0 \pm 2.6 \mu \mathrm{g} \mathrm{g}^{-1}$, being higher than the one found in the literature for Limnoperna fortune (from 2 to $7 \mu \mathrm{g} \mathrm{g}^{-1}$ ). ${ }^{36}$ The vanadium and chromium concentrations in the tissue of the mussel under investigation were higher than the values reported in the literature (from 0.29 to $1.7 \mu \mathrm{g} \mathrm{g}^{-1}$ for $\mathrm{V}$ and $0.61 \pm 0.08 \mu \mathrm{g} \mathrm{g}^{-1}$ for $\mathrm{Cr}$ ) ${ }^{2,20} \mathrm{In}$ the whole mussel, the $\mathrm{Cr}$ concentration $\left(10.0 \pm 1.1 \mu \mathrm{g} \mathrm{g}^{-1}\right)$ was in agreement with the one reported in the literature for the same species. ${ }^{36}$ The chromium uptake (directly from water) by mussels is likely to be very low owing to the limited water solubility of chromium compounds found in the environment and strong adsorption to sediment under most conditions in the environment. ${ }^{40}$

Lead is a non-essential element ${ }^{41}$ that was found in concentrations of $7.2 \pm 1.1$ and $0.20 \pm 0.03 \mu \mathrm{g} \mathrm{g}^{-1}$ for tissue and shell, respectively. For tissue, this value was in agreement with the one found in the literature for other mussel species. ${ }^{42}$ However, the $\mathrm{Pb}$ concentration was lower than the values found for shell. ${ }^{42}$ The lead concentration found in the whole mussel was $0.39 \pm 0.06 \mu \mathrm{g} \mathrm{g}^{-1}$, in agreement with the literature for the same species. ${ }^{36}$ The distribution of $\mathrm{Pb}$ within animals is closely associated with their calcium metabolism, thus, its concentration is higher in the calcium-rich shell than in the soft tissue. ${ }^{43}$

The values found for $\mathrm{Co}$ and $\mathrm{Sr}$ were $1.62 \pm 0.22$ and $0.76 \pm 0.054 \mu \mathrm{g} \mathrm{g}^{-1}$ and $49 \pm 2.9$ and $574 \pm 21 \mu \mathrm{g} \mathrm{g}^{-1}$ for tissue and shell, respectively. These values (for tissue samples) are in agreement with literature data for other mussel species (values ranged from 1.0 to $4.6 \mu \mathrm{g} \mathrm{g}^{-1}$ for Co and 52.2 to $146 \mu \mathrm{g} \mathrm{g}^{-1}$ for $\left.\mathrm{Sr}\right){ }^{20}$ It is important to mention that, unlike other elements, the $\mathrm{Sr}$ concentration was higher in shell by comparison with the tissue of Limnoperna fortunei. This fact was also reported in the literature, ${ }^{2}$ with concentrations ranging from 800 to $950 \mu \mathrm{g} \mathrm{g}^{-1}$ for shell and from 60 to $190 \mu \mathrm{g} \mathrm{g}^{-1}$ for tissue.

For Sn, Mo and $\mathrm{Li}$ the values found were $3.4 \pm 0.6$ and $13.6 \pm 0.4,1.02 \pm 0.18$ and $0.21 \pm 0.01$, and $1.41 \pm 0.23$ and $0.013 \pm 0.001 \mu \mathrm{g} \mathrm{g}^{-1}$ for tissue and shell, respectively. By 
comparison with literature data, ${ }^{20}$ the $\mathrm{Sn}$ concentration in tissue was higher than the reported one, which ranged from 0.003 to $0.31 \mu \mathrm{g} \mathrm{g}^{-1}$. It is important to mention that, as well as for $\mathrm{Sr}$, the $\mathrm{Sn}$ concentration in shell was higher than in tissue. The molybdenum concentration in tissue was in agreement with literature data, ${ }^{20}$ ranging from 0.233 to $4.08 \mu \mathrm{g} \mathrm{g}^{-1}$. The lithium concentration in tissue and shell was not found in the literature.

The silver concentration in this study was $0.140 \pm 0.018 \mu \mathrm{g} \mathrm{g}^{-1}$ in tissue, lower than $0.013 \mu \mathrm{g} \mathrm{g}^{-1}$ in shell. Although Ag is reported for the first time for Limnoperna fortunei, its concentration in tissue is consistent with values reported in the literature for other mussel species (from 0.020 to $0.15 \mu \mathrm{g} \mathrm{g}^{-1}$ ). ${ }^{20}$

Taking into account the various elements in this study, some elements should receive more attention due to its high toxicity. Mercury and As are toxic in the aquatic environment and harmful to humans. ${ }^{20}$ In this study, the $\mathrm{Hg}$ concentration was $0.070 \pm 0.005 \mu \mathrm{g} \mathrm{g}^{-1}$ in tissue while, for shell, it was lower than $0.05 \mu \mathrm{g} \mathrm{g}^{-1}$. Although $\mathrm{Hg}$ is reported for the first time for Limnoperna fortunei, the value found in tissue is in agreement with the one reported for other mussel species (from 0.037 to $0.536 \mu \mathrm{g} \mathrm{g}^{-1}$ ). ${ }^{20,44}$ However, values for shell were not found in the literature. The arsenic concentration for tissue and shell was $3.5 \pm 0.4$ and $0.29 \pm 0.03 \mu \mathrm{g} \mathrm{g}^{-1}$, respectively, lower than the values previously reported for tissue. ${ }^{20,45}$ Arsenic bioaccumulation occurs in aquatic organisms, mainly in lower invertebrates. Bioconcentration factors measured in freshwater invertebrates for several arsenic compounds generally ranged up to twenty. ${ }^{46}$ It is important to point out that no statistical difference (student $t$-test, $p>0.05$ ) was observed between ICP-MS and ICP OES determinations for all elements.

The accuracy of the method was evaluated by using NIST SRM 1566b (Oyster Tissue) and NIST SRM 1640 (trace elements in natural water). Results are summarized in Table 3, respectively. The agreement with certified values for SRM $1566 \mathrm{~b}$ and SRM 1640 was from 90 to $107 \%$ and 92 to $104 \%$, respectively.

Table 3. Results for element concentration (mean \pm standard deviation in $\mu \mathrm{g} \mathrm{g}^{-1}, n=3$ ) in SRM 1566b and SRM 1640

\begin{tabular}{|c|c|c|c|c|c|}
\hline \multirow{2}{*}{ Elements / $\left(\mu \mathrm{g} \mathrm{g}^{-1}\right)$} & \multicolumn{3}{|c|}{ SRM 1566b } & \multicolumn{2}{|c|}{ SRM 1640} \\
\hline & Found ICP OES & Found ICP-MS & Certified & Found ICP-MS & Certified \\
\hline $\mathrm{Ag}$ & $<3.1^{\mathrm{a}}$ & $0.67 \pm 0.04$ & $0.67 \pm 0.009$ & $7.6 \pm 0.1$ & $7.6 \pm 0.2$ \\
\hline $\mathrm{Al}$ & $179 \pm 3$ & nd & $197 \pm 6$ & nd & nd \\
\hline As & $<9.1^{\mathrm{a}}$ & $7.4 \pm 0.4$ & $7.7 \pm 0.6$ & $26.0 \pm 0.3$ & $27.0 \pm 0.4$ \\
\hline B & $<1.45^{\mathrm{a}}$ & nd & - & nd & - \\
\hline $\mathrm{Ba}$ & $7.8 \pm 0.2$ & nd & $8.6 \pm 0.3$ & nd & - \\
\hline $\mathrm{Ca}$ & $803 \pm 11$ & nd & $838 \pm 20$ & nd & - \\
\hline $\mathrm{Cd}$ & $2.3 \pm 0.1$ & $2.5 \pm 0.1$ & $2.5 \pm 0.1$ & $22 \pm 1$ & $23 \pm 1$ \\
\hline Co & $<0.66^{\mathrm{a}}$ & $0.36 \pm 0.02$ & $0.37 \pm 0.01$ & $21 \pm 1$ & $20 \pm 1$ \\
\hline $\mathrm{Cr}$ & nd & $0.64 \pm 0.05$ & - & $37 \pm 1$ & $39 \pm 2$ \\
\hline $\mathrm{Cu}$ & $68 \pm 2$ & $69 \pm 1$ & $72 \pm 2$ & $83 \pm 1$ & $85 \pm 1$ \\
\hline $\mathrm{Fe}$ & $204 \pm 4$ & nd & $206 \pm 7$ & nd & - \\
\hline $\mathrm{Li}$ & nd & $0.33 \pm 0.07$ & $0.31 \pm 0.01$ & $53 \pm 6$ & $51 \pm 1$ \\
\hline $\mathrm{Mg}$ & $1077 \pm 14$ & nd & $1085 \pm 23$ & nd & - \\
\hline $\mathrm{Mn}$ & $<21^{\mathrm{a}}$ & $18.4 \pm 0.9$ & $18.5 \pm 0.2$ & $121 \pm 4$ & $122 \pm 1$ \\
\hline Mo & $<1.10^{\mathrm{a}}$ & $0.22 \pm 0.02$ & - & $47 \pm 2$ & $47 \pm 1$ \\
\hline $\mathrm{P}$ & $7234 \pm 75$ & nd & - & nd & - \\
\hline $\mathrm{Pb}$ & $<8.0^{\mathrm{a}}$ & $0.24 \pm 0.04$ & $0.31 \pm 0.01$ & $26 \pm 2$ & $28 \pm 1$ \\
\hline S & $6544 \pm 39$ & nd & - & nd & - \\
\hline $\mathrm{Sn}$ & $<1.64^{\mathrm{a}}$ & $0.028 \pm 0.006$ & $0.031 \pm 0.008$ & nd & - \\
\hline $\mathrm{Sr}$ & $6.9 \pm 0.2$ & $6.8 \pm 0.5$ & $6.8 \pm 0.2$ & $119 \pm 1$ & $124 \pm 1$ \\
\hline $\mathrm{Ti}$ & $12.7 \pm 1.9$ & $10.2 \pm 0.8$ & - & nd & - \\
\hline V & $<1.25^{\mathrm{a}}$ & $0.59 \pm 0.05$ & $0.58 \pm 0.02$ & $12.9 \pm 0.5$ & $13.0 \pm 0.4$ \\
\hline $\mathrm{Zn}$ & $1401 \pm 18$ & $1402 \pm 27$ & $1424 \pm 46$ & $49 \pm 2$ & $53 \pm 1$ \\
\hline
\end{tabular}

${ }^{a} \mathrm{LOQ}$ : limit of quantification $(10 \sigma, \sigma=$ standard deviation of ten measurements of blank solution), $n=10$; nd: not determined. 
The limits of detection and quantification for ICP OES and ICP-MS for all elements were calculated according to IUPAC recommendations (limits of detection $(3 \sigma, \sigma=$ standard deviation of ten measurements of blank solution), $n=10$ and limits of quantification $(10 \sigma$, $\sigma=$ standard deviation of ten measurements of blank solution), $n=10$ ). The calibration curves for ICP-MS and ICP OES for all elements provided good linearity (correlation coefficient of 0.999). The relative standard deviation (RSD) after the MAD procedure for tissue and shell ranged from 0.9 to $16.6 \%$ and 2.8 to $20.9 \%$ for ICP OES and ICP-MS, respectively.

\section{Conclusions}

This study demonstrated that element determination in Limnoperna fortunei may provide important information on environment pollution. Soft tissue and shell samples of Limnoperna fortunei mussel are efficient accumulators of elements. Results showed that, by using microwaveassisted wet digestion in closed vessels, it was possible to determine 24 elements in tissue, shell and whole Limnoperna fortunei, with suitable accuracy. In addition, $\mathrm{Ag}, \mathrm{As}, \mathrm{B}, \mathrm{Ba}, \mathrm{Ca}, \mathrm{Co}, \mathrm{Hg}, \mathrm{Li}, \mathrm{Mo}, \mathrm{P}, \mathrm{S}, \mathrm{Sn}$ and $\mathrm{V}$ were determined for the first time in tissue and shell of Limnoperna fortunei.

\section{Supplementary Information}

Supplementary data are available free of charge at http://jbcs.sbq.org.br as PDF file.

\section{Acknowledgements}

The authors are grateful to the Coordenação de Aperfeiçoamento de Pessoal de Nível Superior (CAPES), the Conselho Nacional de Desenvolvimento Científico e Tecnológico (CNPq) and the Fundação de Amparo à Pesquisa do Estado do Rio Grande do Sul (FAPERGS) for funds granted to this study.

\section{References}

1. Voets, J.; Bervoets, L.; Blust, R.; Environ. Sci. Technol. 2004, $38,1003$.

2. Cevik, U.; Damla, N.; Kobya, A. I.; Bulut, V. N.; Duran, C.; Dalgic, G.; Bozaci, R.; J. Hazard. Mater. 2008, 160, 396.

3. Perceval, O.; Pinel-Alloul, B.; Méthot, G.; Couillard, Y.; Giguère, A.; Campbell, P. G. C.; Hare, L.; Environ. Pollut. 2002, 118,5 .

4. Darrigran, G. A.; Veliger 1995, 38, 171.
5. Pastorino, G. P.; Darrigran, G. A.; Martin, S. M.; Lunaschi, L.; Neotropica 1993, 39, 34.

6. Boltovskoy, D.; Correa, N.; Cataldo, D.; Sylvester, F.; Biol. Invasions 2006, 8, 947.

7. Oliveira, M. D.; Hamilton, S. K.; Calheiros, D. F.; Jacobi, C. M.; Latini, R. O.; Braz. J. Biol. 2010, 70, 831.

8. Brugnoli, E.; Clemente, J.; Boccardi, L.; Borthagaray, A.; Scarabino, F.; An. Acad. Bras. Cienc. 2005, 77, 235.

9. Mansur, M. C. D.; Santos, C. P.; Darrigran, G. A.; Heydrich, I.; Callil, C. T.; Cardoso, F. R.; Rev. Bras. Zool. 2003, $20,75$.

10. Pareschi, D. C.; Matsumura-Tundisi, T.; Medeiros, G. R.; Luzia, A. P.; Tundisi, J. G.; Braz. J. Biol. 2008, 68, 1107.

11. Avelar, W. E. P.; Martim, S. L.; Vianna, M. P.; Braz. J. Biol. 2004, 64, 739.

12. Sylvester, F.; Boltovskoy, D.; Cataldo, D. H.; Austral. Ecol. 2007, 32, 403.

13. Oliveira, M. D.; Calheiros, D. F.; Jacobi, C. M.; Hamilton, S. K.; Biol. Invasions 2011, 13, 717.

14. Darrigran, G. A.; Pastorino, G.; Tentacle 2003, 11, 1.

15. Burns, M. D. M.; Geraldi, R. M.; Garcia, A. M.; Bemvenuti, C. E.; Capitoli, R. R.; Vieira, J. P.; Biociências 2006, 14, 83.

16. Pestana, D.; Ostrensky, A.; Boeger, W. A. P.; Pie, M. R.; Braz. Arch. Biol. Technol. 2009, 52, 135.

17. Guidi, P.; Frenzilli, G.; Benedetti, M.; Bernardeschi, M.; Falleni, A.; Fattorini, D.; Regoli, F.; Scarcelli, V.; Nigro, M.; Aquat. Toxicol. 2010, 100, 75.

18. Giarratano, E.; Duarte, C. A.; Amin, O. A.; Ecotoxicol. Environ. Saf. 2010, 73, 270.

19. Frenzilli, G.; Bocchetti, R.; Pagliarecci, M.; Nigro, M.; Annarumma, F.; Scarcelli, V.; Fattorini, D.; Regoli, F.; Mar. Environ. Res. 2004, 58, 609.

20. Nguyen, P. C. T.; Nguyen, N. H.; Agusa, T.; Ikemoto, T.; Bui, C. T.; Tanabe, S.; Takeuchi, I.; Fish. Sci. 2010, 76, 677.

21. Voets, J.; Talloen, W.; Tender, T.; Dongen, S.; Covaci, A.; Blust, R.; Bervoets, L.; Aquat. Toxicol. 2006, 79, 213.

22. Welz, B.; Sperling, M.; Atomic Absorption Spectrometry, $3^{\text {rd }}$ ed.; Wiley-VCH: Weinheim, 1999.

23. Pacheco, P. H.; Gil, R. A.; Smichowski, P.; Polla, G.; Martinez, L. D.; J. Anal. At. Spectrom. 2008, 23, 397.

24. Korn, M. G. A.; Santos, G. L.; Rosa, S. M.; Teixeira, L. S. G.; Oliveira, P. V.; Microchem. J. 2010, 96, 12.

25. Antes, F. G.; Mesko, M. F.; Barin, J. S.; Moreira, C. M.; Flores, E. M. M.; Dressler, V. L.; Microchem. J. 2011, 98, 144.

26. Antes, F. G.; Duarte, F. A.; Mesko, M. F.; Nunes, M. A. G.; Pereira, V. A.; Müller, E. I.; Dressler, V. L.; Flores, E. M. M.; Talanta 2010, 83, 364.

27. Pereira, J. S. F.; Mello, P. A.; Moraes, D. P.; Duarte, F. A.; Dressler, V. L.; Knapp, G.; Flores, E. M. M.; Spectrochim. Acta, Part B 2009, 64, 554.

28. Santos, W. P. C.; Hatje, V.; Santil, D. S.; Fernandes, A. P.; Korn, M. G. A.; Souza, M. M.; Microchem. J. 2010, 95, 169. 
29. Gonzalez, M. H.; Souza, G. B.; Oliveira, R. V.; Forato, L. A.; Nóbrega, J. A.; Nogueira, A. R. A.; Talanta 2009, 79, 396.

30. Duarte, F. A.; Pereira, J. S. F.; Barin, J. S.; Mesko, M. F.; Dressler, V. L.; Flores, E. M. M.; Knapp, G.; J. Anal. At. Spectrom. 2009, 24, 224.

31. Mesko, M. F.; Moraes, D. P.; Barin, J. S.; Dressler, V. L.; Knapp, G.; Flores, E. M. M.; Microchem. J. 2006, 82, 183.

32. Nóbrega, J. A.; Nascentes, C. C.; Araújo, G. C. L.; Nogueira, A. R. A.; Pirola, C.; Commun. Soil Sci. Plant Anal. 2007, 38, 2333.

33. Magara, Y.; Matsui, Y.; Gotto, Y.; Yuasa, A.; J. Water Supply Res. Technol. AQUA 2001, 50, 113.

34. Maroñas, M. E.; Darrigran, G. A.; Sendra, E. D.; Breckon, G.; Hydrobiologia 2003, 495, 41.

35. Anton Paar GmbH, Software version v1.27-Synt, Multiwave 3000 - Microwave Sample Preparation System, Austria, 2003.

36. Villela, I. V.; Oliveira, I. M.; Silveira, J. C.; Dias, J. F.; Henriques, J. A. P.; Silva, J.; Mutat. Res. 2007, 628, 76.

37. Joksimovic, D.; Tomic, I.; Stankovic, A. R.; Jovic, M.; Stankovic, S.; Food Chem. 2011, 127, 632.

38. World Health Organization (WHO); Manganese and its Compounds: Environmental Aspects; WHO Publications: Geneva, 2004.
39. Villar, C.; Stripeikis, J.; D’Huicque, L.; Tudino, M.; Troccoli, O.; Bonetto, C.; Hydrobiologia 1999, 416, 41.

40. World Health Organization (WHO); Inorganic Chromium (III) Compounds; WHO Publications: Geneva, 2009.

41. Tomazelli, A. C.; Martinelli, L. A.; Avelar, W. E. P.; Camargo, P. B.; Fostier, A. H.; Ferraz, E. S. B.; Krug, F. J.; Júnior, D. S.; Braz. Arch. Biol. Technol. 2003, 46, 673.

42. Edward, F. B.; Yap, C. K.; Ismail, A.; Tan, S. G.; Water Air Soil Pollut. 2009, 196, 297.

43. Foster, P.; Chacko, J.; Mar. Environ. Res. 1995, 40, 55.

44. Besada, V.; and rade, J. M.; Schultzea, F.; González, J. J.; Cont. Shelf Res. 2011, 31, 457.

45. Stankovic, S.; Jovic, M.; Milanov, R.; Joksimovic, D.; J. Serb. Chem. Soc. 2011, 76, 1725.

46. World Health Organization (WHO), Arsenic and Arsenic Compounds: Environmental Health Criteria 224; WHO Publications: Geneva, 2001.

Submitted: December 9, 2011

Published online: April 3, 2012 